\title{
Managing Marketing Teams
}

Jay Edwards, Murdoch University, USA

Andrew Honeycutt, Shorter University, USA

Craig Cleveland, Saint Leo University, USA

\begin{abstract}
With the emergence of global information and technology, firms have reformulated marketing and technological teaming in a concert effort to accommodate transnational marketing relationships that enable firms to compete in a global business society. Given the competitiveness of organizational distinction and implication, firms have proactively created an internal synergy that enable marketing teams to better excel in an environment of obscurity and uncertainly. Marketing management has evolved into phenomena that require constant reassessment of vision, mission, and strategy in an unrelenting effort to maintain organizational survival and competitiveness in a global recessive business economy. Information technology has greatly inspired this renewed sense of competition; moreover, organizations that embrace the challenge of integrating technology within marketing teams will only become the change agents the business world community will aspire to duplicate for great strategic advantage.
\end{abstract}

Keywords: Marketing; marketing management; Managing Teams; Teams

\section{INTRODUCTION}

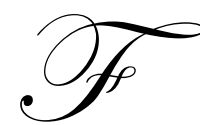

ormally, a team is a group of two or more individuals collectively working toward the same goal (Provitera, 1995). Depending upon the goals of the organization (Cespedes, 1996; Hansen, 1994), the group may be composed of individuals closely tied within organizational and functional boundaries (marketing), or teams may be cross-functional (for example, marketing, accounting, and production), where individuals originate from a variety of disciplines and responsibilities (Hansen, 1994). Teams represent a strategic and formal decision to ensure proper resource support is provided a particular project (El-Ansary, Zabriskie \& Browning, 1993). In this light, the individuals who compose teams typically represent organizational resources combined and aligned to accomplish a specific task or goal. Consistent with the basic contention that customer's seek value (Webster, 1992), marketing teams should be shaped around the needs of customers (Zenger, Musselwhite, Hurson \& Perrin, 1994). Thus, the advantage of marketing teams to buyers rests on having more resources designated to work on their specific needs. Such a buyer-seller linkage is evident in a variety of strategic applications, where such firms as Westin Hotels and Resorts (Tyrer, 1994), NEC Technologies (Damore, 1995), Eastman Kodak Company (Cuneo, 1995), Apple Computer (Hamlin, 1994), and IBM (Gillooly, 1994) are reporting the use of marketing teams to strengthen ties strategically between seller and buyers.

In successful teams the individual members are not controlled, managed, or supervised. Instead, team members are led by a shared vision of the goals and purpose of the organization (Ray \& Bronstein, 1995). The nature of an environment where multiple individuals are collectively working toward one goal suggests involvement strengthens individual performance in a synergistic coupling of resources (Katzenbach \& Smith, 1993). As a result, the underlying purpose of constructing a team is to enhance existing organizational abilities through the coalescing of individuals who offer different strengths (skills, interests, backgrounds) to a joint venture (Cespedes, 1996).

\section{ENVIRONMENT FOR MARKETING TEAMS}

When human resources are brought together, the strong competitive leverage gained (Shapiro, 1987) suggests that using marketing teams can be a profitable strategy (Deeter-Schmelz \& Ramsey, 1995). This opportunity occurs in an environment where buyers' expectations of sellers are escalating, and marketers are faced with the challenge of differentiating and extending the utility of their products (Webster, 1992). Further, the needs 
of buyers are increasingly becoming complex, requiring buyers and sellers to have the ability to exchange information rapidly. Consequently, marketing teams as a competitive advantage are now being widely reported in both the business (Cuneo, 1995; Krajewski, 1994) and academic press (Cespedes, 1996; Olson, Walker \& Ruekert, 1995). The extensive use of marketing teams as an efficient, low cost strategy (El-Ansary, Zabriskie \& Browning, 1993) demonstrates expensive resources (employees) can be collectively directed in harmony to mutually important organizational goals of buyers and sellers. Such versatility suggests marketers may become more seamless across organizational boundaries (Prabhaker, Goldhar \& Lei, 1995) as they expand marketing teams to include personnel from a variety of internal (finance, accounting, and production), and external (customers) sources (Webster, 1992).

Within business-to-business markets, however, opportunities are particularly bright for the future use of marketing teams because of the nature of these markets (Webster, 1992). For example, industrial markets typically require high investments to make exchanges, extended time to complete transactions, a large number of individuals involved in decisions, highly competitive markets, the need for close relationships between principal decisions makers (buyer and sellers), and increasingly complex and intertwined financial attachments involving both buyers and sellers (El-Ansary, Zabriskie \& Browning, 1993). Due to the complexity of these marketplace arrangements, the use of marketing teams within markets will increasingly prevail. Current examples of how the use of marketing teams have expanded in markets are illustrated through the widely accepted practices of using cross functional and national account teams to work with large buyers (Webster, 1992).

The commingling of IT and the utilization of marketing teams is offered as one method of enriching organizational performance. This opportunity exists because the underlying premise of team effectiveness relies on the inclusion of multiple individuals imputing knowledge (information) to a single strategy (El-Ansary, Zabriskie \& Browning, 1993), and corresponding, the role of IT is to deliver knowledge (information) to the user (Bloom, Milne \& Adler, 1994). As such, information is the common crucial element that collectively directs marketing team activities and defines the difference between high and low marketing performance. Further, this commingling is also possible because of the barriers inherent to effective teams and the subsequent impact IT has on these barriers suggests (Bloom, Milne \& Adler, 1994).

\section{BARRIERS TO EFFECTIVE TEAMS}

The ability of the group to communicate effectively often dictates success or failure (Varney, 1989). Hence, the role of information exchange in a team setting assumes a more complex framework than simpler communication channels involving only two discrete parties (a single source and receiver). The level of communication complexity escalates because of the processes required to secure information relevant to the particular objective or assignment. In simple two party interactions the communication processes are typically less intricate than those in teams due to opportunities for problems (for example, lost, misdirected, or miscommunicated information) are minimized as the number of communication points (senders-receivers) are reduced (Parker, 1994). The process of communication is inherently more complex as intragroup interaction escalates. Thus, while the use of multiple member teams provides many benefits, the inherent dynamics of teams create interaction obstacles (size, proximity of members, boundary management, cost, member empowerment, organizational support, performance assessment and accountability, complex membership, and getting people to work together) that frequently limit productivity (Monaghan, 1995; Parker, 1994). These barriers to team effectiveness revolve around basic interaction problems and are compatible with the key role that communication plays in the success of failure teams (Reiste \& Hubrich, 1995). Consequently, the composition of teams (Cespedes, 1996) as well as physical, psychological, and responsibility barriers all may interfere with group communication, and in turn, team performance.

\section{WHY TECHNOLOGICAL TEAMING WORKS}

The basic premise in linking information systems with marketing teams rests with the rationale that jointly embracing both entities produces positive performance results (Norman, 1995). In a more specific sense, the performance of teams increases as the interaction quality escalates (Cespedes, 1996). Correspondingly, given that a basic role of IT is to communicate accurate information rapidly, and marketing teams represent multiple parties collectively collaborating on a joint project, opportunities exist for positive linkages between the use of IT and marketing teams (DeSanctis \& Jackson, 1994). For instance, a Chicago shopping center developed a marketing 
team to collect customer information at different retail locations for an electronic database. The marketing team is provided valuable data (marital status, income, homeowner status) by customers, which are then used by technology teams to expand mutual understanding of buyers (Gattuso, 1994).

Importantly, team interaction occurs through the development of common goals of group members and the sharing of responsibilities, which in turn creates a synergistic output that should exceed individual production (Gattuso, 1994). The initial goal of successful IT in the team setting is to enrich the elements of interaction and sharing. From this perspective and congruent with the marketing environment it is evident that long term goals of integrating technology and teams should be consistent with the need to improve the effectiveness of intelligence development and decision making (Jessup \& Valacich, 1993). Based on the basic communicative nature of IT (Bloom, Milne \& Adler, 1994), it is important to consider whether the barriers of teams can be sufficiently minimized by IT. Through IT, however, it is possible for large team membership situations not to impact productivity unduly through the efficiencies of communication enabled by electronic linking (DeSanctis \& Jackson, 1994). Although marketing teams engage in a variety of behaviors, communication is a factor that primarily governs their success (Varney, 1989). In conjunction with its ability to improve communication (DeSanctis \& Jackson, 1994), the usage of IT offers many positive impacts on marketing teams. The support and rationale for technology enrichment of teams occurs because communications are positively impacted by the actual technology, as well as the improved processes created by the technology (Jessup \& Valacich, 1993).

\section{STRATEGIC IMPLICATIONS}

Despite the many advantages empowered by IT, these advancements have not always been embraced by marketers (Dyer, 1987; Goslar, 1987; Kurtz \& Boone, 1987; Steinberg \& Plank, 1987). Consequently, it should not be assumed that IT will be automatically and enthusiastically consumed by marketing teams. In fact, because the environment influences of technology usage are strong (Raymond, 1990; Turnipseed, Burns \& Hodges, 1991), the integration of teams with IT requires a strong commitment on the part of the supporting organization(s). As such, upper management plays a crucial role in integrating IT within the organization (Benton \& Gray, 1993; Hartman, Lundberg, White \& Barnett, 1995, Yoon, Guimaraes \& O'Neal, 1995), indicating its use by marketing teams will be dictated by the willingness of management to accept technology in this role. This integration can be organizationally encouraged through the participation (training of personnel, availability of the technology, technical support) of the marketing team, and the resource support team (Turnipseed, Burns \& Hodges, 1991). In contrast, however, when management does not actively seek to integrate marketing teams and technology, it is unlikely this assimilation will occur (Yoon, Guimaraes \& O'Neal, 1995).

The basic premise of using technological teaming originates from the value it offers buyers and sellers within these markets. Although this value can be found in many places, improved relationships between buyers and sellers represent a particularly useful and desired outcome of technological teaming (Benton \& Gray, 1993). The capabilities provided by IT enhance the abilities of all team members to assess and act on a variety of situations (trends and problem areas) that are equally important to the buyers and seller. Additionally, the nature of this integration (the availability of computers for buyers and sellers that are easily linked) encourages the inclusion of the client as part of the team, which in turn more closely ties together and enriches relationships between buyers and sellers suggests Hartman, Lundberg, White and Barnett (1995). This value is illustrated when a manufacturer requires several commodity products provided by different firms (several different firms and their subsidiaries each can provide the products needed). If one seller is able to link electronically the manufacturer with a marketing teams (composed subsidiary members) to monitor systemically buyer inventory levels, this can be used to ensure this sellers' products are available as needed (Benton \& Gray, 1993).

\section{AUTHOR INFORMATION}

Jay Edwards holds a Ph.D. in Organizational Management from Capella University, a Master of Business Administration from Troy State University, a Bachelor of Science in Business Management from National-Louis University, and an Associate of Science in Information Systems from Atlanta Technical Institute. His research interest encompasses the impact of cognitive, affective and communicative processes in organisational change and knowledge to enhance the learning processes 
Dr. Andrew E. Honeycutt is the recipient of the Doctor of Business Administration degree in Marketing from Harvard University and the Masters in Business Administration degree from Boston University. He is also a Northwestern University Nissan Marketing Fellow. Andrew currently is the Distinguished Fellow of Business of Shorter University, Rome, Georgia,

Dr. Craig S. Cleveland is the recipient of the Doctor of Business Administration degree in Management from Argosy University and the Masters of Business Administration degree from Shorter College. He is an adjunct faculty member at Shorter College in Rome, Georgia and Saint Leo University in Duluth, Georgia.

Dr. Cleveland's expertise comes in the field of management and leadership studies. He also works as a criminal investigator with the Atlanta Judicial Public Defender's office. Dr. Cleveland served as a Special Agent with the Drug Enforcement Administration from 1985-2001. Throughout his career, he held the position of Assistant Country Attaché at the American Embassy in Ankara, Turkey. He has trained and lectured many foreign national police officers in India, Russia, Egypt, Romania, Pakistan, United Kingdom, Bolivia, Peru, Panama and many other countries.

\section{REFERENCES}

1. Benton, A. M. \& Gray, G. L. (1993). Managerial and technical factors related to strategic impact of information technology. Journal of Information Technology Management, 4, 15-27.

2. Bloom, P. N., Milne, G. R., \& Adler, R. (1994). Avoiding misuse of new information technologies: Legal and societal considerations. Journal of Marketing, 58, 98-110.

3. $\quad$ Cespedes, F. V. (1996). Managing Marketing Linkages. Upper Saddle River, NJ: Prentice Hall.

4. $\quad$ Cuneo, A. Z. (1995). Kodak's new vision. Advertising Age, 66, 38-53.

5. Damore, K. (1995). NECT hones product line, gains ground in U.S. market, Computer Reseller News, 24, 81-95.

6. DeSanctis, G. \& Jackson, B. M. (1994). Coordination of information technology management: Team based structures and computer-based communications systems. Journal of Management Information Systems, 10, $85-110$.

7. Dyer, R. F. (1987). An integrated design for personal computers in the marketing curriculum. Journal of the Academy of Marketing Science, 15, 16-24.

8. El-Ansary, A. I., Zabriskie, N. B., \& Browning, J. M. (1993). Sales teamwork: A dominant strategy for improving sales force effectiveness. Journal of Business and Industrial Marketing, 8(3), 65-72.

9. Gattuso, G. (1994). Kiosks build mall loyalty and database. Direct Marketing, 57, 26-39.

10. Gillooly, B. (1994). IBM creates team to better manage PS/2, ValuePoint. Computer Reseller News, 17, 5988.

11. Goslar, M. D. (1987). Marketing and the adoption of microcomputers: An application of diffusion theory. Journal of the Academy of Marketing Science, 15, 42-48.

12. Hamlin, C. (1994). Team building a global team at apple computer, Employment Relations Today, 21, 5568.

13. Hansen, P. G. (1994). Getting your team on the same side. Financial Executive Magazine, 3, 43-49.

14. Hartman, S., Lundberg, O., White, M., \& Barnett, T. (1995). Information processing techniques in planning: An investigation of preferences of executive planners. Journal of Business Research, 33, 13-34.

15. Jessup, L. M. \& Valacich, U. L. (1993). Group Support Systems: New Perspectives, New York: Macmillan.

16. Katzenbach, J. R. \& Smith, D. K. (1993). The wisdom of teams. Boston, MA: Harvard Business School Press.

17. Krajewski, S. (1994). Barnhart kicks off ad effort to boost U.S. Olympic Festival, Adweek, 16, 5-20.

18. Kurtz, D. L., \& Boone, L. E. (1987). The current status of microcomputer usage in the marketing programs of AACSB-accredited Colleges and Universities. Journal of the Academy of Marketing Science, 15, 10-15.

19. Monaghan, R. (1995). Customer management teams are here to stay. Marketing News, 29, 4-18.

20. Norman, R. P. (1995). Becoming information technology visionaries. Financial Executive, 11, 1-15.

21. Olson, E. M., Walker, O. C., \& Ruekert, R. W. (1995). Organizing for effective new product development: The moderating role of product innovativeness. Journal of Marketing, 59, 48-62.

22. Parker, G. M. (1994). Cross functional teams. San Francisco, CA: Jossey-Bass. 
23. Prabhaker, P. R., Goldhar, J. D. \& Lie, D. (1995). Marketing implications of newer manufacturing technologies. Journal of Business \& Industrial Marketing, 10, 48-58.

24. Provitera, M. J. (1995). Sales management and sales teamwork. American Marketing Association Summer Proceedings, 176-184.

25. Ray, D. \& Bronstein, H. (1995). Teaming up: Making the transition to a self-directed, Team-based organization. New York: McGraw Hill.

26. Raymond, L. (1990). Organizational context and information system success: A contingency approach. Journal of Management Information Systems, 6, 3-20.

27. Reiste, K. K. \& Hubrich, A. (1995). Frigidaire experience. National Productivity Review, 14, 45-60.

28. Shapiro, B. F. (1987). The new intimacy. Boston, MA: Harvard Business School Publishing Division.

29. Steinberg, M., \& Plank, R. (1987). Expert systems: The integrative sales management tool of the future. Journal of the Academy of Marketing Science, 15, 49-51.

30. Turnipseed, D. L., Burns, O. M., \& Hodges, F. J. (1991). Attitudes towards computers in an information intensive environment: A field study of the insurance industry. Journal of Applied Business Research, 7, 123-130.

31. Tyrer, K. (1994). Marc Pujalet. Adweek, 35, 40.

32. Varney, G. H. (1989). Building productive teams. San Francisco, CA: Jossey-Bass.

33. Webster, F. E. (1992). The changing role of marketing in the corporation. Journal of Marketing, 56, 1-17.

34. Yoon, Y., Guimaraes, T., \& O’Neal, Q. (1995). Exploring the factors associated with expert systems success. MIS Quarterly, 19, 83-106.

35. Zenger, J. H., Musselwhite, E, Hurson, K. \& Perrin, C. (1994). Leading teams: Mastering the new role. Homewood, IL: Business One Irwin. 


\section{NOTES}

